\title{
Genetic characterisation of isolates of Listeria monocytogenes from man, animals and food
}

\author{
D. J. TROTT, I. D. ROBERTSON and D. J. HAMPSON*
}

School of Veterinary Studies, Murdoch University, Murdoch, Western Australia 6150, Australia

\begin{abstract}
Summary. Multilocus enzyme electrophoresis was used to assess genetic relationships between 95 isolates of Listeria monocytogenes, most of which were isolated in Australia and New Zealand from man, animals and food. The isolates were separable into two major genetic divisions; the majority of those from human patients and animals were in division $I$, and the majority from those foods that were not specifically associated with human listeriosis were in division II. Isolates in division I were virulent, whereas many isolates from food were probably less virulent and did not pose a large threat to human health. However, isolates from certain foods, particularly paté, were indistinguishable from those causing disease in man, and the consumption of these products represented a clear risk factor for infection. Isolates from infected human patients in Australia and New Zealand belonged to the same clone of serotype $4 \mathrm{~b}$ that has been responsible for major epidemics in the northern hemisphere. However, a separate clone of serotype 1/2b strains, present in both Australia and New Zealand, was responsible for two major outbreaks that occurred in Western Australia in 1978-80 and 1990-91.
\end{abstract}

\section{Introduction}

Listeria monocytogenes is an ubiquitous soil saprophyte that can survive at low temperatures and resist harsh environmental conditions. It causes listeriosis, a disease of man and animals of low morbidity but high mortality, which may manifest itself as meningoencephalitis, septicaemia, abortion or stillbirth. Listeriosis in man was once rare. However, in the last 10 years, the number of cases reported has risen steadily and several large epidemics have been recorded..$^{1-4}$ In these epidemics, conclusive evidence for foodborne transmission was demonstrated. Foodborne transmission has also been documented in several sporadic cases of the disease..$^{5.6}$

Several techniques for subspecific differentiation of L. monocytogenes have been used to study the epidemiology of listeriosis. Serotyping of somatic and flagellar antigens has been widely used. Thirteen different serotypes have been recognised but most isolates are of serotype $1 / 2 \mathrm{a}, 1 / 2 \mathrm{~b}$ or $4 \mathrm{~b} .{ }^{7}$ Phage typing has been commonly used but has the disadvantage that not all strains are typable. ${ }^{8}$ DNA restriction endonuclease analysis has been used for strain differentiation, ${ }^{9.10}$ and recently, multilocus enzyme electrophoresis (MEE) has been shown to be a powerful means of genetically characterising isolates on the basis of the electrophoretic mobilities of their constitutive enzymes. ${ }^{11 / 3}$
In these studies, natural populations of $L$. monocytogenes have been shown to have substantial genetic diversity. Despite this, most epidemics of listeriosis in separate parts of the world have involved only two clones of bacteria, both of serotype $4 \mathrm{~b}$. One of them has been isolated frequently from cases of listeriosis in animals, and it is postulated that it has enhanced virulence. ${ }^{11-13}$

Listeriosis has occurred sporadically in Australasia. Epidemics of listeriosis have been reported in New Zealand, ${ }^{14-16}$ and in Western Australia (WA) ${ }^{17}$ but no predisposing risk factors were identified. In 1990, the number of recorded cases of listeriosis in WA increased. In this outbreak, five stillbirths and six cases of neonatal infection were reported during a 6-month period. In all cases, infection of the fetus followed a self-limiting, flu-like illness in the mother. High-risk foods were examined for listeria and several products were recalled. ${ }^{18}$

The purposes of the present study were to determine relationships between isolates from human patients in WA and New Zealand, and between these isolates and those isolated in outbreaks in the northern hemisphere, and to look for possible sources of infection in man in WA by examining isolates from food and animals.

\section{Materials and methods}

\section{Bacterial isolates}

The source and epidemiological characteristics of the 95 isolates of L. monocytogenes examined are 
Table I. Electrophoretic type (ET) designation and epidemiological data of isolates located in division $I$ in the figure

\begin{tabular}{|c|c|c|c|c|}
\hline $\begin{array}{c}\text { ET } \\
1\end{array}$ & \multicolumn{2}{|l|}{ Isolates } & $\begin{array}{c}\text { Source } \\
\text { Animal, avian liver }\end{array}$ & $\begin{array}{l}\text { Location } \\
\text { and date }\end{array}$ \\
\hline 1 & $\begin{array}{l}12119 \\
5848 \\
15188,5795,4075,449 \\
191 \\
4851,3992 \\
186 \\
4046 \\
485 \\
190 \\
91 / 441^{\text {a }}, 91 / 619^{\mathrm{b}}, 91 / \\
91 / 688^{\text {d }} \\
43256,43257(\text { ATCC) }\end{array}$ & & $\begin{array}{l}\text { Animal, avian liver } \\
\text { Animal, caprine brain } \\
\text { Animal, bovine brain } \\
\text { Animal, bovine M.L.N. } \\
\text { Animal, unknown species } \\
\text { Animal, porcine foetal liver } \\
\text { Human, swab from arm } \\
\text { Human, neotal PM } \\
\text { Human, CSF culture } \\
\text { Human, perinatal isolates } \\
\text { Food, ex refrigerator } 91 / 619 \\
\text { Ref. Mexican soft cheese }\end{array}$ & $\begin{array}{ll}\text { Vic } & (1979) \\
\text { Vic } & (1979) \\
\text { Vic }(1980) \\
\text { WA }(1983) \\
\text { Vic }(1980) \\
\text { WA }(1980) \\
\text { Vic }(1980) \\
\text { WA }(1977) \\
\text { WA }(1980) \\
\text { NZ }(1991) \\
\text { NZ }(1991) \\
\text { US }(1984)\end{array}$ \\
\hline 2 & \multicolumn{2}{|c|}{$\begin{array}{l}6533 \\
1514,1516,1527,1530,1539 \\
16316 \\
89.083 \\
28,29 \\
32,34,35,36,37,38,39,40,41,42,43 \\
50 \\
56,57 \\
91 / 148^{\mathrm{e}}, 91 / 149^{\mathrm{f}}, 91 / 169^{\mathrm{g}} \\
14 / 136 \\
30 / 31 \\
23,23 / 27,25 / 30,31 / 32,41 / 33,48 / 34 \\
30\end{array}$} & $\begin{array}{l}\text { Animal, caprine brain } \\
\text { Human, perinatal isolates } \\
\text { Human, adult blood culture } \\
\text { Human, neonate blood culture } \\
\text { Human, faecal culture } \\
\text { Human, perinatal isolates } \\
\text { Human, peritoneal culture } \\
\text { Human, perinatal isolates } \\
\text { Human, perinatal isolates } \\
\text { Food, breakfast sausage } \\
\text { Food, chicken } \\
\text { Food, chicken liver paté } \\
\text { Env, paté factory mincer }\end{array}$ & $\begin{array}{l}\text { Vic }(1978) \\
\text { WA }(1978) \\
\text { WA }(1989) \\
\text { WA }(1989) \\
\text { WA }(1990) \\
\text { WA }(1990) \\
\text { WA }(1991) \\
\text { WA }(1991) \\
\text { NZ }(1991) \\
\text { WA }(1990) \\
\text { WA }(1990) \\
\text { WA }(1990) \\
\text { WA }(1990)\end{array}$ \\
\hline 3 & $\begin{array}{l}189 \\
487 \\
335,336,6 / 80\end{array}$ & & $\begin{array}{l}\text { Animal, bovine abortion } \\
\text { Animal, wallaby lung } \\
\text { Food, chicken/pet food }\end{array}$ & $\begin{array}{l}\text { WA (1974) } \\
\text { WA }(1981) \\
\text { WA }(1990)\end{array}$ \\
\hline 4 & \multicolumn{2}{|l|}{488} & Animal, agouti uterus & WA (1982) \\
\hline 5 & \multicolumn{2}{|c|}{$\begin{array}{l}537 \\
64,360 \\
21 / 79,437 / 79,721 / 79,947 / 79 \\
375 / 81,357 / 81,99 / 85,246 / 86 \\
2089\end{array}$} & $\begin{array}{l}\text { Animal, bovine brain } \\
\text { Animal, caprine brain } \\
\text { Animal, ovine brain } \\
\text { Animal, ovine CSF }\end{array}$ & $\begin{array}{l}\text { Vic }(1981) \\
\text { WA }(1978) \\
\text { WA }(1979-86) \\
\text { WA }(1990)\end{array}$ \\
\hline \multirow[t]{3}{*}{6} & \multicolumn{2}{|l|}{$91 / 255^{\mathrm{h}}$} & Human, perinatal isolate & NZ (1991) \\
\hline & $\begin{array}{l}\text { Super- } \\
\text { script }\end{array}$ & Serotype* & Phage type $\uparrow$ & \\
\hline & $\begin{array}{l}\mathrm{a} \\
\mathrm{b} \\
\mathrm{c} \\
\mathrm{d} \\
\mathrm{e} \\
\mathrm{f} \\
\mathrm{g} \\
\mathrm{h}\end{array}$ & $\begin{array}{c}4 \mathrm{~b} \\
4 \mathrm{~b} \\
4 \mathrm{~b} \\
4 \ddagger \\
1 / 2 \mathrm{~b} \\
1 / 2 \mathrm{~b} \\
1 / 2 \mathrm{~b} \\
4 \mathrm{c}\end{array}$ & $\begin{array}{l}2389: 47: 52: 108: 340 \\
2389: 2425: 3274: 47: 52: 108: 340 \\
2425: 3274 \\
2425: 3274: 2671 \\
575 \\
575 \\
575 \\
\text { NT }\end{array}$ & 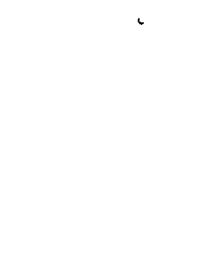 \\
\hline
\end{tabular}

WA, Western Australia; Vic, Victoria; NZ, New Zealand; US, United States.

NT, not typable.

* Flagellar antigens determined by Dr P. André, Institute of Hygiene and Epidemiology, Brussels.

† Performed by Dr J. Rocourt, Institut Pasteur, Paris.

$\ddagger$ Flagellar antigens not examined (food isolate).

shown in tables I and II. Thirty of the isolates were from clinically diseased animals. Of 34 human isolates, 27 were from cases of perinatal listeriosis. The remainder were from adult patients and were from various sources including blood, CSF, faeces, peritoneal fluid and a cutaneous skin lesion. Seven of the isolates from the cases of perinatal listeriosis together with one isolate from food in the refrigerator of one of the patients were from New Zealand and were provided by Patricia Short. The remainder of the isolates were from WA and were obtained from the WA State Health Laboratory Services and the WA Department of Agriculture. Of $27 \mathrm{WA}$ isolates from food, nine were from cooked chicken, six from comminuted meat product, six from chicken liver paté, one from smoked salmon paté, three from chicken or beef pet food and one both from pork sausage and a meat product of unknown origin. All were isolated during the 1990 WA epidemic. ${ }^{19,20}$ One environmental sample was from the factory where the paté mentioned above was manufactured (R. Mogyorosy, personal communication). Two American Type Culture Collection (ATCC) reference strains isolated from Mexican-style soft cheese during an epidemic that occurred in Los 
Table II. Electrophoretic type (ET) designation and epidemiological data of isolates located in division II in the figure

\begin{tabular}{|c|c|c|c|}
\hline ET & Isolates & Source & $\begin{array}{l}\text { Location } \\
\text { and date }\end{array}$ \\
\hline 7 & $\begin{array}{l}9677 \\
1187\end{array}$ & $\begin{array}{l}\text { Animal, ovine brain } \\
\text { Animal, bovine foetal liver }\end{array}$ & $\begin{array}{ll}\text { Vic } & (1979) \\
\text { WA } & (1989)\end{array}$ \\
\hline 8 & $16 / 23$ & Food, comminuted product & WA (1990) \\
\hline 9 & $\begin{array}{l}22,28 / 185,15 / 26,74 / 38,76 / 39,87 / 40,337 \\
24 \\
413\end{array}$ & $\begin{array}{l}\text { Food, chicken/pet food } \\
\text { Food, salmon paté } \\
\text { Food, unknown origin }\end{array}$ & $\begin{array}{l}\text { WA }(1990) \\
\text { WA }(1990) \\
\text { WA }(1990)\end{array}$ \\
\hline 10 & $2 / 41$ & Food, comminuted product & WA (1990) \\
\hline 11 & 7973 (NCTC) & Ref. strain, guinea pig & UK (1926) \\
\hline 12 & $\begin{array}{l}1 / 22,9 / 24,17 / 26,18 / 27 \\
29 / 188\end{array}$ & $\begin{array}{l}\text { Food, comminuted product } \\
\text { Food, beef pet food }\end{array}$ & $\begin{array}{l}\text { WA }(1990) \\
\text { WA }(1990)\end{array}$ \\
\hline 13 & $\begin{array}{l}10457 \\
27\end{array}$ & $\begin{array}{l}\text { Animal, caprine brain } \\
\text { Human, adult blood culture }\end{array}$ & $\begin{array}{ll}\text { Vic } & (1980) \\
\text { WA } & (1990)\end{array}$ \\
\hline
\end{tabular}

WA, Western Australia; Vic, Victoria; UK, United Kingdom.

Angeles County, California in $1984,{ }^{2}$ and NCTC strain 7973 , once proposed as the new type strain for L. monocytogenes, ${ }^{21}$ were included to permit comparison with the results of others.

\section{Serotyping and phage typing}

Serotyping and phage typing information was available for the New Zealand isolates (see table I). Isolates from the WA State Health Laboratory Services were typed as $1 / 2$ with commercially available sera according to the method of Seeliger and Höhne. ${ }^{22}$ Of these, isolates 1514, 1527, 36 and 43 were further serotyped by Dr J. McLauchlin of the Central Public Health Laboratory, Colindale Avenue, London as being $1 / 2 \mathrm{~b}$, whereas isolate 27 was $1 / 2 \mathrm{a}$. ATCC reference strains from the USA were serotype $4 \mathrm{~b}$ and the NCTC reference strain was serotype 1/2a.

\section{Microbial culture and enzyme extraction}

Organisms were grown aerobically in Brain Heart Infusion Broth (BHIB, Oxoid CM 225) at $37^{\circ} \mathrm{C}$ on a rocking platform. Single colonies were first inoculated into $3 \mathrm{ml}$ of BHIB and incubated for $24 \mathrm{~h}$. The cultures were then transferred aseptically to $100 \mathrm{ml}$ of BHIB, incubated for a further $24 \mathrm{~h}$ and finally transferred to $1 \mathrm{~L}$ of BHIB and incubated for $36 \mathrm{~h}$. Samples were plated on to Columbia agar containing defibrinated sheep blood $5 \%$ and checked for purity after incubation.

Bacteria were harvested by centrifugation at $15000 \mathrm{~g}$ for $20 \mathrm{~min}$, resuspended in $c .150 \mathrm{ml}$ of phosphatebuffered saline $(\mathrm{pH} 7.2)$ and then centrifuged again at $15000 \mathrm{~g}$ for $20 \mathrm{~min}$. The cells were suspended in $2 \mathrm{ml}$ of $10 \mathrm{~mm}$ Tris-1 mм EDTA-0.5 mM NADP (pH 6.8) on ice and broken up by three 1 -min cycles of sonication with a $100 \mathrm{~W}$ sonic probe (Labsonic 1510). Gramstained films were examined to confirm adequate cell disruption. After centrifugation at $20000 \mathrm{~g}$ for $20 \mathrm{~min}$ at $4^{\circ} \mathrm{C}$, the supernates were dispensed into microcentrifuge tubes in $150 \mu \mathrm{l}$ volumes and stored at $-70^{\circ} \mathrm{C}$

\section{Multilocus enzyme electrophoresis}

The supernates were electrophoresed in horizontal starch $11.4 \%$ gels and the electrophoretic mobilities of the following 18 enzymes were determined by staining for specific enzyme activity, as recommended: $:^{23}$ alanine dehydrogenase (ALA), leucyl-glycyl-glycine peptidase (LGG), mannose-6-phosphate isomerase (MPI), 6-phosphogluconate dehydrogenase (PGD), NADP-dependent glutamate dehydrogenase (GDH), phosphoglucose isomerase (PGI), fumarase (FUM), glucose-6-phosphate dehydrogenase (GPD), phosphoglucomutase (PGM), NAD-dependent glyceraldehyde 3-phosphate dehydrogenase (GP), nucleoside phosphorylase (NP), adenylate kinase (ADK) and superoxide dismutase (SOD) were assayed in buffer $\mathrm{A}$; aldolase (ALD) and isocitrate dehydrogenase (IDH) were assayed in buffer B; $\alpha$-naphthyl esterases 1 and 2 (ES 1 and 2) and acid phosphatase (ACP) were assayed in buffers $\mathrm{D}$ and $\mathrm{F}$ respectively.

\section{Analysis}

Genetic diversity (h) for each enzyme locus was calculated from the formula $\mathrm{h}=1-\sum x_{i}^{2}[n /(n-1)]$, where $x_{i}$ is the number of isolates in the sample, $n$ is the sample size and $n /(n-1)$ is a correction for bias in small samples. ${ }^{24}$ Isolates with identical allele profiles at all loci were recorded as belonging to the same electrophoretic type (ET). Genetic distance between ETs was calculated as the proportion of fixed loci at which dissimilar alleles occurred, with a computer clustering programme (Phentree) based on the TAXAN2 package. ${ }^{25}$ The programme created a phenogram by the Unweighted Pair-Group Method of Arithmetic Averages (UPGMA) clustering fusion strategy for determining Squared Euclidean Distance (SED), which is a convenient measure of dissimilarity 
in haploids. ${ }^{25,26}$ SED can be equated with genetic distance between ETs and was used to illustrate genetic relationships within and between clusters.

\section{Results}

Twelve of the enzymes analysed were polymorphic for the 95 isolates examined. The other six (ADK, SOD, PGI, NP, ALD and GDH) were monomorphic. All isolates were typable and yielded distinct banding patterns for all the 18 enzyme loci. No null alleles were recorded. The mean number of alleles/locus was 1.83. Genetic diversity (h) was recorded for each enzyme and the mean genetic diversity for all loci $(\mathrm{H})$ was calculated as 0.23 (table III). Thirteen distinct allelic profiles were identified and these were divided into two major divisions at a genetic distance of 0.402 (equivalent to fixed allele differences at an average of $7 \cdot 2$ of the 18 loci) (figure). Division I comprised ETs 1-6 and contained $74(78 \%)$ of the isolates. Most were in ETs 1 and 2, which contained 19 and 36 isolates respectively (table I).

All but one of the 34 isolates from man were located in division I, with 26 belonging to ET 2 . Included within this ET were five perinatal isolates from the 1978-80 WA outbreak, 13 serotype $1 / 2$ perinatal isolates from the 1990-91 WA outbreak, and three serotype $1 / 2 \mathrm{~b}$ perinatal isolates from New Zealand. This ET also contained a peritoneal culture isolate from an adult in 1991, isolates from two faecal cultures from adults in 1990 and isolates from blood cultures from a sporadic case of listeriosis in an adult, and from a neonate, both obtained in 1989. ET 1 contained six isolates from man, including three New Zealand isolates of serotype $4 \mathrm{~b}$ and three isolates from sporadic cases of listeriosis in Australia. These were cultured from adult CSF in 1980, from a dead neonate in 1977 and from an arm lesion in 1980. The other isolate from New Zealand was from a case of perinatal listeriosis, was of serotype $4 \mathrm{c}$ and belonged to ET 6 . The final isolate was from a WA adult with meningitis and septicaemia, and was distinct in being of serotype $1 / 2 \mathrm{a}$ and belonging to ET13 in division II.

Twenty six $(87 \%)$ of the 30 isolates from diseased animals were located in division I. Ten isolates from various species were in ET 1, two isolates in ET 3 and single isolates in ETs 2 and 4. ET 5 contained two caprine and eight ovine isolates obtained from a region around Albany in WA over an 8-year period. One other ovine WA isolate was also located in this group together with a Victorian isolate from a bovine brain. The other four animal isolates were located in division II, two being in ET 7 and one each in ETs 11 and 13 (table II).

Sixteen isolates from food were located in division II and 14 in division I. ET 9 in division II contained the most (nine) food isolates and many came from chicken products, including pet food made from chicken meat. Of the six strains from comminuted meat, four were in
Table III. Allele frequencies and genetic diversity at 18 enzyme loci in 13 ETs of Listeria monocytogenes

\begin{tabular}{|c|c|c|c|c|}
\hline \multirow{2}{*}{$\begin{array}{l}\text { Enzyme } \\
\text { locus* }\end{array}$} & \multicolumn{3}{|c|}{ Frequency of indicated allele } & \multirow{2}{*}{$\begin{array}{c}\text { Genetic } \\
\text { diversity (h) }\end{array}$} \\
\hline & 1 & 2 & 3 & \\
\hline LGG & $0 \cdot 37$ & 0.29 & \multirow[t]{5}{*}{$0 \cdot 33$} & 0.67 \\
\hline ALA & 0.44 & 0.56 & & 0.50 \\
\hline GPD & 0.36 & 0.64 & & 0.47 \\
\hline ES1 & 0.74 & 0.26 & & 0.39 \\
\hline GP & 0.78 & 0.22 & & 0.35 \\
\hline MPI & 0.18 & 0.02 & \multirow[t]{3}{*}{0.80} & 0.33 \\
\hline FUM & $0 \cdot 20$ & 0.80 & & $0 \cdot 32$ \\
\hline $\mathrm{ACP}$ & 0.80 & 0.20 & & 0.32 \\
\hline PGM & 0.16 & 0.82 & \multirow[t]{10}{*}{0.02} & $0 \cdot 30$ \\
\hline PGD & 0.16 & 0.84 & & 0.27 \\
\hline ES2 & 0.09 & 0.91 & & $0 \cdot 17$ \\
\hline IDH & 0.99 & 0.01 & & 0.02 \\
\hline ADK & 1.00 & & & 0.00 \\
\hline SOD & 1.00 & & & 0.00 \\
\hline NP & 1.00 & & & 0.00 \\
\hline PGI & 1.00 & & & 0.00 \\
\hline ALD & 1.00 & & & 0.00 \\
\hline GDH & 1.00 & & & $0 \cdot 00$ \\
\hline \multicolumn{4}{|c|}{ Mean genetic diversity per locus $(\mathrm{H})$} & 0.23 \\
\hline
\end{tabular}

* See text for enzyme identification.

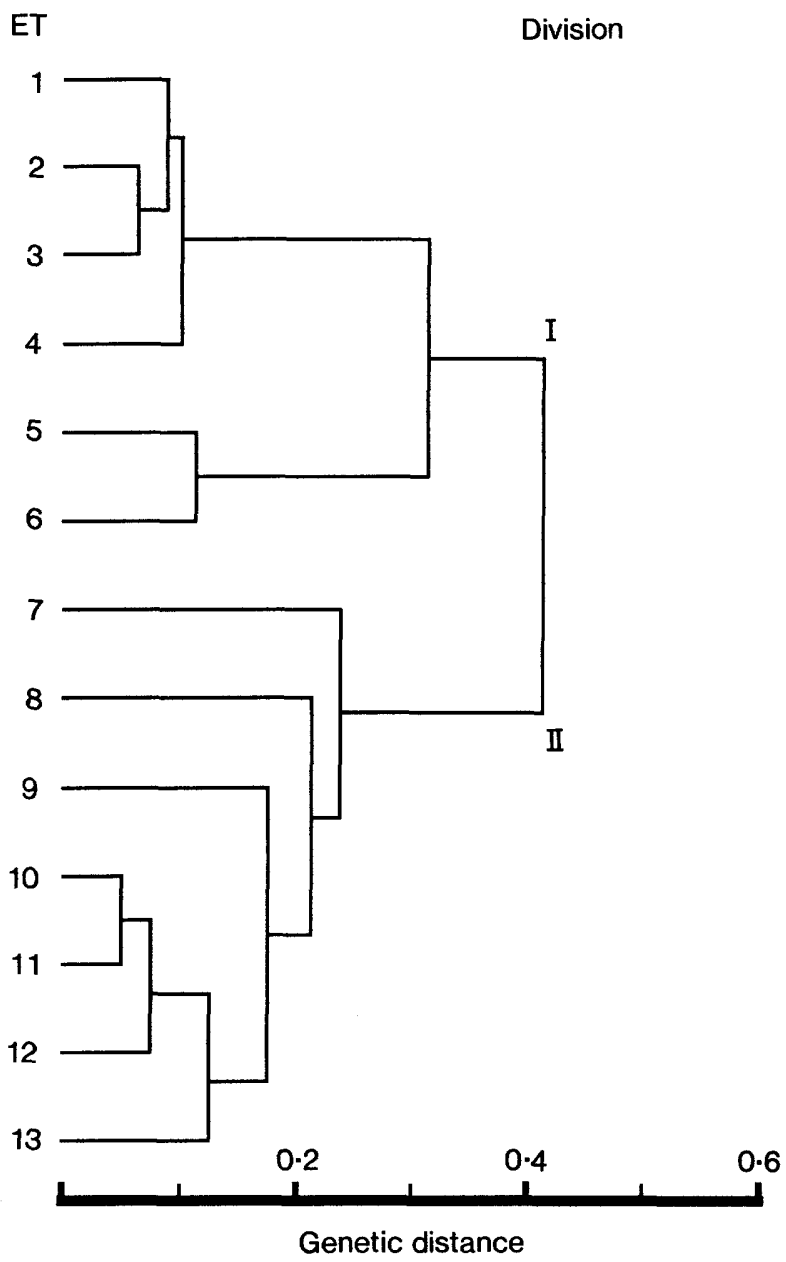

Figure. Phenogram of genetic distances, calculated as the proportion of fixed allelic differences, amongst 13 ETs of L.monocytogenes clustered by UPGMA strategy. Numbering of ETs corresponds to tables I and II. Two divisions of ETs are shown at a genetic distance of 0.4 . 
ET 12, together with an isolate from beef sold as pet food. Isolates from food found in division I were located in three closely related ETs. A New Zealand isolate from food in a patient's refrigerator and the two ATCC reference strains from Mexican-style soft cheese were in ET 1. ET 2 contained eight isolates from food in WA in 1990. Of these, six were from chicken liver paté from a single manufacturing source and the other two were from breakfast sausage and processed chicken. An environmental sample from a mincer at the factory where the pate was manufactured was also in this ET. The remaining three isolates were from cooked chicken and chicken pet food and were in ET 3.

\section{Discussion}

Piffaretti et al. ${ }^{11}$ and Bibb et al. ${ }^{12}$ recognised the existence of two primary phylogenetic divisions of L. monocytogenes, separated in their two studies by genetic distances of 0.54 and 0.44 respectively. ETs in one division contained all the isolates of serotypes $1 / 2 b, 3 b, 4 a$ or $4 b$ that were examined, and ETs in the second division contained all their isolates of serotypes $1 / 2 \mathrm{a}$ or $1 / 2 \mathrm{c}$.

In the present study, the 95 isolates of L. monocytogenes were also divided into two distinct divisions (I and II), separated by a genetic distance of 0.402 . Division I contained ETs 1-6 and ETs 7-13 were in division II. The principal enzymes responsible for this division were GP, FUM, GPD and MPI. The presence of allele 2 for the enzyme GP was exclusive to isolates in division II, and for the three remaining enzymes a single allele was usually present in division II isolates. All the known isolates of serotypes $4 \mathrm{~b}$ and $1 / 2 \mathrm{~b}$ were in division $I$, suggesting that our division $I$ is analogous to the division I of both Piffaretti et al. ${ }^{11}$ and Bibb et al. ${ }^{12}$ Seventy-four isolates were located in this division, including 59 of the 64 isolates from human and animal clinical cases. The 21 isolates in division II were mainly from food. The fact that a high proportion $(92.2 \%)$ of strains isolated from clinical cases belonged to division I suggests that organisms located in this division are more likely to be virulent than those in division II.

With the exception of single isolates in ETs 6 and 13, all isolates from human clinical cases were located in the two closely related ETs, 1 and 2, separated by a genetic distance of $0 \cdot 09$. Our ET 1, containing the two ATCC strains, was equivalent to ET 1 of Piffaretti et al. ${ }^{11}$ and ET 14 of Bibb et al. ${ }^{12}$ Organisms belonging to this ET have been responsible for several epidemics in man throughout the world, and it has been suggested that they represent a subtype with enhanced virulence. ${ }^{11-13}$ Therefore, this bacterial clone is also present in Australia and New Zealand and is not restricted to the northern hemisphere. Although strains in ET 1 have not caused any recorded epidemic disease in Australasia, sporadic infection has been widespread and associated with various manifestations of the disease. Thus, ET 1 organisms appear to have no particular neurotrophic or viscerotrophic preference. Those that were typed in this study were of serotype $4 \mathrm{~b}$, but the New Zealand isolates could be divided further by phage typing, suggesting that there were additional phenotypic differences within this clone.

All 11 isolates from cases of perinatal listeriosis in WA during 1990 were in ET 2, which strongly suggests that the epidemic was from a common source. Isolates obtained in 1989 from one adult and two perinatal cases were also from this ET, as were isolates from two perinatal cases and from one non-pregnant adult infection that occurred in WA during 1991. This suggests that there was a continuing source of infection that was still present even after surveillance was initiated by the WA Health Department during 1990. Furthermore, the five isolates from the 1978-80 WA perinatal listeriosis outbreak were also located in ET 2. Representative isolates from both outbreaks were of serotype $1 / 2 b$. The results suggest that the same subtype caused both WA listeriosis epidemics. The three isolates of serotype $1 / 2 \mathrm{~b}$ from New Zealand cases of perinatal listeriosis were also in ET 2, demonstrating that infection with this bacterial clone is widespread.

The isolate of serotype 1/2a that was located in ET 13 was from a case of meningitis and septicaemia in an immunocompromised person that occurred in WA during the time of the perinatal listeriosis epidemic. Although isolated in WA in 1990, the subtype was distinct, and could be classed as causing a sporadic infection during an epidemic. The single isolate of serotype $4 \mathrm{c}$ from New Zealand, in ET 6, can also be classed as causing a sporadic infection, as the remainder of the New Zealand isolates were located in two different ETs. The division of the seven human isolates from New Zealand into three ETs suggests at least three separate sources of infection.

Of the 30 isolates of $L$. monocytogenes from animals with clinical disease, 26 were in division I. ET 1 isolates infected several different animal species, a feature also observed by others. ${ }^{13}$ ET 5 included 10 isolates from cases of meningoencephalitis in sheep and goats in the south west of WA between 1978 and 1986. This subtype is, therefore, common in this locality, is relatively stable and is virulent for small ruminants.

Sixteen of 30 isolates of L. monocytogenes from food were in division II, and were not associated with animal or human clinical cases. Nine isolates were in ET 9 and most were from various forms of cooked chicken, suggesting that this subtype is commonly carried by this species. Their most likely origin was from carcass contamination with gastrointestinal contents during processing. This may have introduced the organism into the processing environment where subsequent poor hygiene aided its survival and dissemination into the final product. ${ }^{27}$ Four of six isolates from comminuted raw meat were in ET 12, also suggesting a possible common source of contamination for these products. Many isolates from foods 
were different from those causing most human and animal disease suggesting that widespread contamination of food with L. monocytogenes may not be as significant as was once thought.

The most important isolates from food were those in ETs 1,2 and 3 in division 1. Only ETs 1 and 2 contained isolates from man, animals and food. Both isolates from Mexican-style soft cheese from the 1984 Californian outbreak were in ET 1, as was isolate 91/688 from contaminated food in the refrigerator of a New Zealand woman who had a stillbirth some time after consuming the food (P. Short, personal communication). An isolate of the same ET, although possessing different phage reactions, was isolated from this case of perinatal listeriosis $(91 / 619)$. Similarly, eight isolates from foods in WA during the 1990 epidemic were in ET 2, together with the epidemic strain. One of these isolates was from raw barbeque sausage, one from a processed chicken roll, and the remainder were from chicken liver paté from a single manufacturing source. In addition, an environmental isolate from a mincer at the factory where the pate was produced was also in ET 2, together with two isolates of L. monocytogenes cultured from the stools of two patients who had suffered food-poisoning after consuming the same brand of paté. Paté may often be contaminated with L. monocytogenes. ${ }^{28}$

Although consumption of contaminated paté was associated with the WA epidemic in 1990, a causal relationship could not be fully substantiated. Firstly, contamination of foods with organisms of ET 2 may be widespread since three different foodstuffs were contaminated with the same organism. Many foods that have been shown to contain the organism, such as processed salads and soft cheeses, were not included in

\section{References}

1. Schlech WF, Lavigne PM, Bortolussi RA et al. Epidemic listeriosis - evidence for transmission by food. $N$ Engl J Med 1983; 308: 203-206.

2. Linnan MJ, Mascola L, Lou XD et al. Epidemic listeriosis associated with Mexican-style cheese. $N$ Engl J Med 1988; 319: $823-828$

3. Bille J. Epidemiology of listeriosis in Europe, with special reference to the Swiss outbreak. In: Miller AJ, Smith JL, Somkuti GA (eds) Foodborne listeriosis. Amsterdam, Elsevier. 1990: 71-74.

4. Fleming DW, Cochi SL, MacDonald KL et al. Pasteurized milk as a vehicle of infection in an outbreak of listeriosis. $N$ Engl J Med 1985; 312: 404-407.

5. Kerr KG, Dealler SF, Lacey RW. Materno-fetal listeriosis from cook-chill and refrigerated food. Lancet 1988; 2: 1133.

6. Schwartz B, Broome CV, Brown GR et al. Association of sporadic listeriosis with consumption of uncooked hot dogs and undercooked chicken. Lancet 1988; 2: 779-782.

7. McLauchlin J. Listeria monocytogenes, recent advances in the taxonomy and epidemiology of listeriosis in humans. $J$ Appl Bacteriol 1987; 63: 1-11.

8. McLauchlin J, Audurier A, Taylor AG. The evaluation of a phage typing system for Listeria monocytogenes for use in epidemiological studies. J Med Microbiol 1986; 22: 357-365. the study, and these foods may represent additional sources of infection. Secondly, although MEE is a highly sensitive strain typing technique, it is not necessarily completely accurate for it does not screen the entire bacterial genome. Nevertheless, the fact that isolates from contaminated paté, the factory environment and food-poisoning cases were all of the same ET is highly suggestive that pate was the vehicle for foodborne transmission. This is substantiated by other epidemiological evidence. ${ }^{18}$ One patient who was delivered of a stillborn baby had been consuming paté during her pregnancy. L. monocytogenes was also isolated from paté in the refrigerator of a second patient who was delivered of a stillborn baby. Unfortunately, this isolate was not available for inclusion in this study. No case studies were performed on the remainder of the patients to identify likely sources of infection.

This study suggests that consumption of contaminated paté represents a definite risk of infection. It reinforces the need for accurate surveillance of highrisk foods, so as to prevent susceptible consumers from being exposed. Although listeriosis is a rare disease, the high mortality associated with many of the infections outweighs the necessary expense of control measures. Foods contaminated with strains of low virulence do not represent a high risk to community health, but the dissemination of virulent strains such as those from ETs 1 and 2 should remain a matter of community concern.

This work was supported by a grant from Murdoch University. We thank R. Mogyorosy and Patricia Short for providing human isolates from Western Australia and New Zealand, respectively, to J. McLauchlin for serotyping representative isolates, to Ruth Reuter and $\mathrm{N}$. Buller for animal isolates and to A. Lymbery and Jenny Woodward for technical advice and assistance.

9. Szabo EA, Desmarchelier PM. A comparative study of clinical and food isolates of Listeria monocytogenes and related species. Epidemiol Infect 1990; 105: 245-254.

10. Wesley IV, Ashton F. Restriction enzyme analysis of Listeria monocytogenes strains associated with food-borne epidemics. Appl Environ Microbiol 1991; 57: 969-975.

11. Piffaretti J-C, Kressebuch H, Aeschbacher $\mathrm{M}$ et al. Genetic characterization of clones of the bacterium Listeria monocytogenes causing epidemic disease. Proc Natl Acad Sci USA 1989; 86: 3818-3822.

12. Bibb WF, Gellin BG, Weaver R et al. Analysis of clinical and food-borne isolates of Listeria monocytogenes in the United States by multilocus enzyme electrophoresis and application of the method to epidemiological investigations. Appl Environ Microbiol 1990; 56: 2133-2141.

13. Boerlin P, Piffaretti J-C. Typing of human, animal, food, and environmental isolates of Listeria monocytogenes by multilocus enzyme electrophoresis. Appl Environ Microbiol $1991 ; 57$ : 1624-1629.

14. Becroft DMO, Farmer K, Seddon RJ et al. Epidemic listeriosis in the newborn. $B M J 1971 ; 3: 747-751$.

15. Lennon D, Lewis B, Mantell C et al. Epidemic perinatal listeriosis. Pediatr Infect Dis J 1984: 3: 30-34.

16. Faoagali JL, Schousboe M. Listeriosis in Christchurch 1967-1984. NZ Med J 1985; 98: 64-66.

17. Niels le Soeüf $\mathbf{P}$, Walters BNJ. Neonatal listeriosis. A summer outbreak. Med J Aust 1981; 2: 188-191. 
18. Watson C, Jackson $\mathbf{M}$, Kelly $\mathbf{H}$, Ott $\mathbf{K}$, Knowles $\mathbf{S}$, Wells J. Listeria outbreak in Western Australia. Comm Dis Inf $1990 ; 24: 9-12$.

19. Seneviratna P, Robertson J, Robertson ID, Hampson DJ. Listeria species in foods of animal origin. Aust Vet $J 1990$; 67: 384 .

20. Trott D, Seneviratna P, Robertson J. Listeria in cooked chicken, paté and mixed smallgoods. Aust Vet $J 1991$; 68 : 249-250.

21. Jones D, Seeliger HPR. Designation of a new type strain for Listeria monocytogenes: request for an opinion. Int $J$ Syst Bacteriol 1983; 33: 429 .

22. Seeliger HPR, Höhne K. Serotyping of Listeria monocytogenes and related species. In: Bergan T, Norris JR (eds) Methods in microbiology. New York, Academic Press Inc. 1979: 31-49.

23. Selander RK, Caugant DA, Ochman $\mathrm{H}$ et al. Methods of Multilocus Enzyme Electrophoresis for bacterial popu- lation genetics and systematics. Appl Environ Microbiol $1986 ; 51: 873-884$

24. Nei M. Estimation of average heterozygosity and genetic distance from a small number of individuals. Genetics $1978 ; 89: 583-590$

25. Burr EJ. Division sorting with mixed character types I. Standardisation of character values. Aust Comp J 1968; 1 : 97-99.

26. Burr EJ. Division sorting with mixed character types II. Fusion strategies. Aust Comp J 1970; 2: 98-103.

27. Carosella JM. Occurrence of Listeria monocytogenes in meat and poultry. In: Miller AJ, Smith JL, Somkuti GA (eds) Foodborne listeriosis. Amsterdam, Elsevier. 1990: $165 \cdots 173$.

28. Morris IJ, Ribeiro CD. The occurrence of Listeria species in paté: the Cardiff experience 1989. Epidemiol Infect 1991; 107: 111-117. 